\title{
CROPS PRODUCTIVITY MODELS UNDER THE CULTIVATION IN DIFFERENT BY METEOROLOGICAL CONDITIONS YEARS ON THE IRRIGATED LANDS OF THE SOUTH OF UKRAINE
}

\author{
Piliarska O. O., Kokovikhin S. V.
}

\section{INTRODUCTION}

Climate change threatens our ability to achieve global food security, eradicate poverty and achieve sustainable development. Greenhouse gas emissions from human activities are an important factor of climate change, as they lead to the heat accumulation in the atmosphere, causing global warming. Climate change significantly impacts agricultural productivity, including changes in precipitation, air temperatures, droughts, floods and areas of geographical distribution of pests and diseases. Therefore, under such conditions, agrarian science must develop and implement in production such systems of agriculture that would be adapted to the adverse effects of climate change $\mathrm{e}^{1,2}$.

The main directions of intensification of modern agriculture include the focus on significant incrtease in crop production on the existing land areas under the reduction of anthropogenic pressure on the environment, soil fertility and the expenses of non-renewable natural resources maintanence, provision for the ecological sustainability of agroecosystems. Such biologized scientific approaches to modern agriculture should combine traditional knowledge with modern

\footnotetext{
${ }^{1}$ Гадзало Я.М., Вожегова Р.А., Коковіхін С.В., Біляєва I.М., Дробітько А.В. Наукове обгрунтування технологій вирощування кукурудзи на зрошуваних землях із урахуванням гідротермічних чинників і змін клімату. Зрошуване землеробство. Херсон, 2020. Вип. 73. С. 21-26.

2 Агрокліматичні ресурси півдня України та їх раціональне використання : монографія / Лимар А.О., Лимар В.А., Коковіхін С.В. Домарацький Є.О. Херсон : Грінь Д.С., 2015. 246 с.
} 
technologies adapted to climate change and local needs of agricultural producers, especially small farms 3,4 .

In the southern regions of Ukraine, the main factor limiting the realization of the biological and genetic potential of crops and reducing the efficiency of agro-ecological potential is the lack of moisture. Irrigation significantly eliminates this deficit and thus contributes to the increase in the efficiency of agroecological potential and the degree of its manifestation in the form of the actual level of yield. Agroecological potential is one of the components of natural resource and economic potential. It is defined as the ability of soils, atmosphere, hydrosphere and bioty of the region to provide certain economic products in specific socio-economic conditions of land use, based on biological productivity, without bringing the system of natural resources to irreversible destruction and sharp deterioration of its dynamic qualities $5,6,7$.

Modern intensive systems of agriculutre must basically ensure the increase in crop yields, restoration, preservation and increase in soil fertility at the expense of the factors of agricultural intensification fertilizers application, melioration, irrigation, mechanization, automation, soil protection, resource-saving and environmentally friendly technologies, as well as through the improvement of tools and machines. Being combined, this should increase the economic efficiency of land use. Therefore, all these means of intensification should be used taking into account the latest advances in agrarian science and best practices, and provide for highly productive use of suitable land for the cultivation of the most valuable high-yielding crops, varieties and hybrids. The ratio between individual crops in a crop rotation under

3 Зубець М.В. Наукові основи агропромислового виробництва в зоні Степу України. Київ : Аграрна наука, 2004. С. 359-363.

4 Жуйков Г.Є., Димов О.М. Нормативи витрат матеріально-технічних ресурсів при вирощуванні основних зернових культур : науково-методичний посібник. Херсон : Айлант, 2004. 20 с.

5 Іващенко О.О., Рудник-Іващенко О.I. Напрями адаптації аграрного виробництва до змін клімату. Вісн. аграр. науки. 2011. № 8. С. 10-12.

6 Ушкаренко В.О., Вожегова Р.А., Голобородько С.П., Коковіхін С.В. Статистичний аналіз результатів польових дослідів у землеробстві: монографія. Херсон : Айлант, 2013. 403 с.

7 Коковіхін С.В., Писаренко П.В., Пілярський В.Г., Ніколайчук М.Г., Нікішов О.О., Дробітько А.В. Оптимізація структури посівних площ на зрошуваних землях 3 урахуванням показників гідромодулю системи та біологічних потреб культур. Зрошуване землеробство: збірник наукових праць. Херсон : Айлант, 2013. Вип. 60. С. 30-32. 
intensive systems of agriculture is determined taking into account the state, economic and individual needs in accordance with market requirements in different agricultural products, farm specialization and its soil and climatic conditions $^{8,9}$. It is necessary to model the productivity of crops at their cultivation in the years with different weather conditions on the irrigated lands of southern Ukraine, because it is of a great scientific and practical importance in terms of rational use of natural potential of the region and stabilization of agricultural production in Ukraine.

\section{Scientific substantiation of the adaptation of modern cultivation technologies in the arid regions of the Steppe of Ukraine}

The agroecological potential of the Steppe zone of Ukraine is directly connected with climate change, especially in the natural hydrothermal conditions in some local areas, which can vary significantly over the years. Thus, according to meteorological observations, it is proved that changes in climatic indices of Kherson oblast have a close reverse relationship between the fluctuations in average annual air temperatures and the amount of precipitation (Fig. 1). It is determined that over the last 30 years the average annual air temperature has a steady trend to increase, and in 2019 it reached a maximum of $12.9^{\circ} \mathrm{C}$. Precipitation tends to fluctuate significantly, with a minimum in the recent years of $310 \mathrm{~mm}$ (2017).

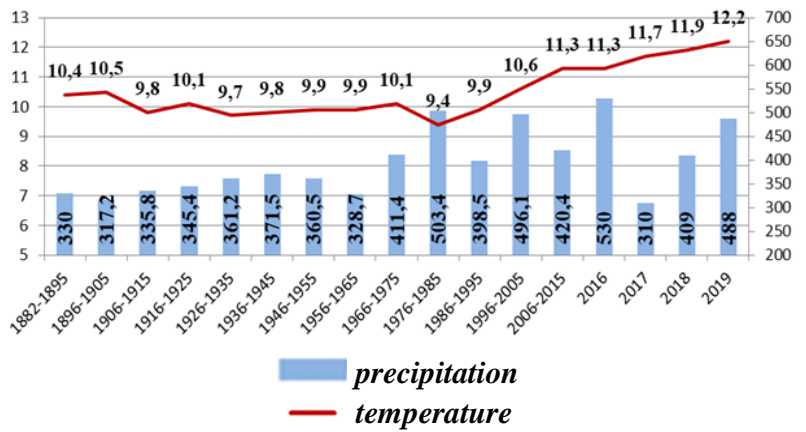

Fig. 1. Average precipitation and average annual air temperatures (according to the agro-meteorological station of Kherson (1882 -2019))

8 Сайко В.Ф. Наукові основи землеробства в контексті змін клімату. Вісн. аграр. науки. 2008. № 11. С. 5-10.

9 Тараріко Ю.О. Розробка грунтозахисних ресурсо- та енергозберігаючих систем ведення сільськогосподарського виробництва 3 використанням комп’ютерного програмного комплексу. Київ : Нора-Друк, 2002. 122 с. 
It should also be considered that the increase in the temperature of atmospheric air in different temperature ranges manifests in uneven manner. Thus, in 2012, the total increase in the sum of active temperatures was $19 \%$, and the increase in the sum of effective temperatures above $15^{\circ} \mathrm{C}$ was $63 \%$.

Such a distribution testifies about the income on the soil surface of greater by $63 \%$ thermal energy in the summer, which led to an increase in the average ten-day soil temperature in July 2012 at the depth of $5 \mathrm{~cm}$ from $26.7^{\circ} \mathrm{C}$ to $31.1^{\circ} \mathrm{C}\left(+4.4^{\circ} \mathrm{C}\right)$, and at the depth of $20 \mathrm{~cm}$ from $25.9^{\circ} \mathrm{C}$ to $29.9^{\circ} \mathrm{C}\left(+4.0^{\circ} \mathrm{C}\right)$, which directly impacts the productivity of cereals and legumes.

In the conditions of climate change there is a change in soil temperature, therefore the issue of the terms of sowing of the major crops in the Southern region of Ukraine is relevant. The increase in soil temperature, the processes of assimilation and synthesis of organic matter increase, but at the same time the intensity of plant respiration increases. In this regard, with an excessive increase in temperature, a situation may arise in which the processes of synthesis of substances and their use for respiration are on the same level. That is, the plant will be in the so-called state of the compensation point. And with a sharp decrease in soil temperature in plants, metabolic processes are inhibited, and sometimes even disrupted, which can lead to some extent to the death of crops.

By changing the sowing dates in the spring, it is possible to create better conditions for plant growth and development and avoid adverse conditions at the critical stages of development and use the accumulated moisture.

An example of adaptation of sunflower sowing dates in the Southern region of Ukraine in the conditions of regional climate change. Nowadays, there is no common scientific opinion on the optimal terms of sunflower sowing. Because different varieties and hybrids respond differently to sowing dates, and given that many new hybrids have appeared in production in recent years, which differ from their ancestors in the tempo of ripening, morpho-biological features, increased resistance to shading, diseases, lodging, have higher yields and product quality, it is relevant and important for production to determine the optimal terms of sowing of this crop under different soil and climatic conditions in order to improve plant growth and development and increase productivity per unit area.

Scientists and practitioners provide data on the terms of sowing, which are contraversary. Some authors claim that the optimal 
temperature in the time of sowing is $6-9^{\circ} \mathrm{C}$, while some recommend to sow when a soil temperature is $16^{\circ} \mathrm{C}$, and other point on the optimal temperature of $10-12^{\circ} \mathrm{C}$. In the southern regions of Ukraine, the average soil temperature of $10-12^{\circ} \mathrm{C}$ calendly coincides with the mid-April, while the optimal temperature for germination is $20^{\circ} \mathrm{C}$. The optimal time for sowing sunflower hybrids, taking into account their biological features, is in the period when the temperature at the depth of seed placement is $10-12^{\circ} \mathrm{C}$. Under the conditions of early sowing, the period of germination prolongs for 3-4 weeks, the seedlings are uneven, thinned. Under the late sowing, the topsoil often lacks moisture.

The optimal soil temperature for sowing sunflower is $10-12^{\circ} \mathrm{C}$. In the southern region of Ukraine, the average soil temperature of $10-12^{\circ} \mathrm{C}$ calendly is in the month of April. During the period covered by the study (1990-2019), the transition of the average daily soil temperature at the depth of $10 \mathrm{~cm}$ through $+12^{\circ} \mathrm{C}$ in the spring fluctuated from the beginning to the end of April. In most years, the transition of the average daily soil temperature at the depth of $10 \mathrm{~cm}$ through $+12^{\circ} \mathrm{C}$ occurred from 6 to 20 April (Fig. 2).

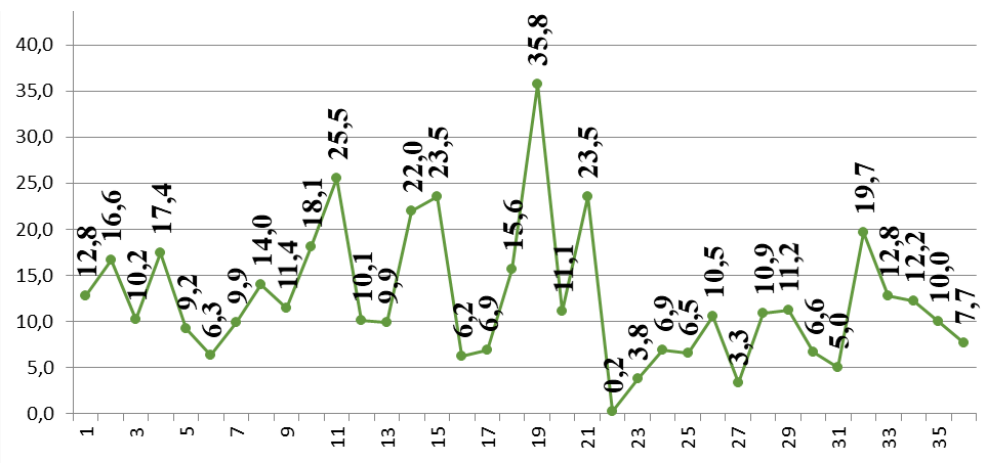

Fig. 2. Average ten-day precipitation in April (1990-2019) by the data of Kherson agrometeorological station

Meteorological phenomena such as frost should also be taken into account. According to the long-term observations of the Kherson Regional Center of Hydrometeorology, on average there are from 5 to 8 days with fros tin April in Kherson oblast. In some years, the number of days with frost can be from 10 to 20 days. 
The Institute of Irrigated Agriculture for a long time has been conducting scientific investigations on the monitoring the changes in the regional climate of the Steppe zone of Ukraine. Our study has shown that during the 135-year period of instrumental observations, there were significant fluctuations in both air temperature and precipitation in Kherson oblast. During this time, there were three periods of warming. At the same time, current warming is more noticeable than previous ones. The temperature rises all the seasons of each year.

For the study period (1990-2019), there is a tendency to increase in the average annual air temperature according to the Kherson Regional Center of Hydrometeorology (Fig. 3).

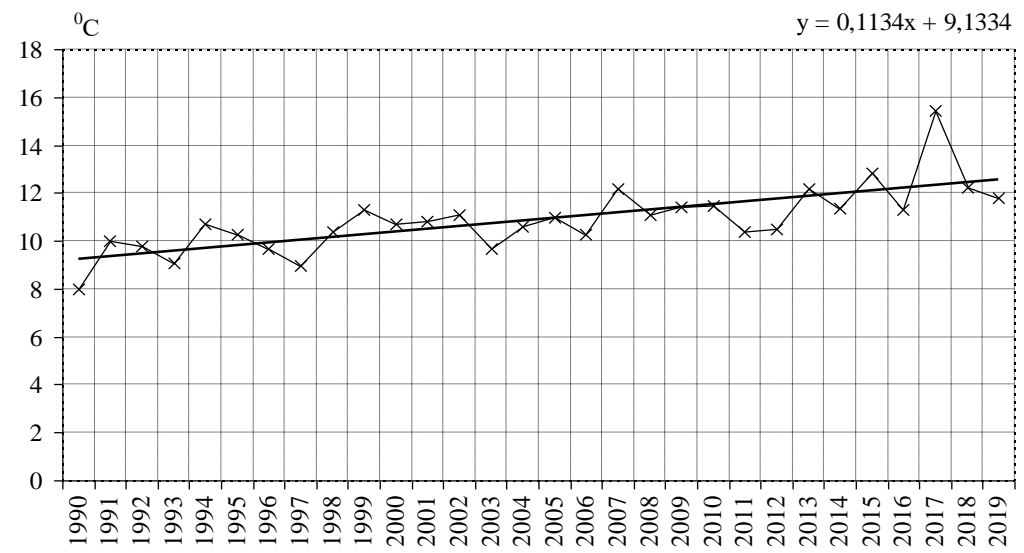

Fig. 3. Average annual air temperature (according to Kherson agrometeorological station)

The tempo of the increase in the average annual air temperature: in the period from 1990 to 1999 is $+0.1812^{\circ} \mathrm{C}$ per year, in the period from 1990 to 2009 it is $+0.1143^{\circ} \mathrm{C}$ per year, and from 1990 to 2019 it is $+0.1134^{\circ} \mathrm{C}$ per year.

In the period of the study (1990-2018) there is a tendency to the increase in the average annual air temperature according to HMS Kherson during the growing season, which is confirmed by the regression equation (Fig. 3). The tempo of the average annual air temperaturte increase is: in the period from 1990 to $1999-0.117^{\circ} \mathrm{C}$ per year, in the period from 1990 to $2009-0.0839^{\circ} \mathrm{C}$ per year, and from 1990 to $2019-0.0961^{\circ} \mathrm{C}$ per year. 
During the stuidied period (1990-2019), there is a tendency to a slight increase in the average annual precipitation and the decrease in the average precipitation according to Kherson agrometeorological station.

Climate change increases the risks in agricultural production, so scientists are faced with the need to modernize the conventional model of agricultural production considering the global and regional climate change.

The Intergovernmental Panel on Climate Change has expressed concern about the negative impact of climate change on crop yields and identified the ways to mitigate the impact of global change through the reduction of greenhouse gas emissions.

According to scientists ${ }^{10,11}$, there is a high probability that global warming will lead to deterioration of climatic conditions on 2 million hectares of land, and the territory of Zaporizhzhia, Kherson, Mykolaiv and Odesa oblasts may become unsuitable for agriculture.

In December 2015, the 21st Conference of the Parties to the UN Framework Convention on Climate Change adopted a new international climate agreement - the Paris Agreement. The Paris Agreement set a goal of keeping global temperatures on the Earth within $2^{\circ} \mathrm{C}$ by 2100 , but greenhouse gas emissions in the signatory countries to this agreement cause global temperatures to rise to $3.5^{\circ} \mathrm{C}$ by 2100 . If the development of agriculture in the future is considered depending on the scenarios of carbon development of the world, we can identify three scenarios of climate change for the world by 2100: no action - raising the temperature to $4.5^{\circ} \mathrm{C}$ with global emissions of about 150 in t; current variant $-\mathrm{CO}_{2}$-eq. $3.5^{\circ} \mathrm{C}$ at the reduction of global emissions to 80 in $\mathrm{t}$ $\mathrm{CO}_{2}$-eq, at the temperature up to $2^{\circ} \mathrm{C}$ at the global emissions of $10 \mathrm{in} \mathrm{t}$ $\mathrm{CO}_{2}$-eq. Ukraine has set its goal of reducing emissions by $40 \%$ until 2030 in comparison to the emissions of 1990.

Based on the above-mentioned analysis, a methodological approach to achieving the goal of the study is based, which is grounded on two scenarios of climate change and, accordingly, areas of agricultural development: the first scenario is a conventional (baseline) climate change scenario based on further climate change and its forecasts and does not provide for a gradual transition to carbon agriculture; the second

${ }^{10}$ Полупан М.І., Соловей В.Б., Величко В.А. Класифікація грунтів України. Київ : Аграрна наука, 2005. С.144-156.

11 Третяк А.М., Бобміндра Д.І. Земельні ресурси України та їх використання. Київ, 2003. 144 с. 
one is a Paris-based climate change scenario hrounded on carbon and adaptive agriculture.

An increase in the air temperature and uneven distribution of precipitation, which have a character of showers, are of a local character in the warm period and do not provide effective accumulation of moisture in the soil have led to an increase in the number and intensity of drought phenomena.

Scientists predict that the humidification regime in Ukraine will change significantly by the middle of the XXI century. There will be a significant heterogeneity both in time and space throughout the year. All this will lead to a change in the boundaries of soil and climatic zones and, as a consequence, the conditions of crops cultivation, their yields and terms of sowing and harvesting ${ }^{12}$.

Table 1 presents the long-term results of the study conducted by the scientists of the Institute of Irrigated Agriculture of NAAS on the impact of sowing terms on the yield of major crops (in this case, winter wheat).

Table 1

Yield of winter wheat depending on sowing terms at the experimental plots of the Institute of Irrigated Agriculture of NAAS, t/ha [12]

\begin{tabular}{|c|c|c|c|c|c|}
\hline $\begin{array}{c}\text { Sowing } \\
\text { terms }\end{array}$ & $\mathbf{1 9 6 7 - 1 9 8 4}$ & $\mathbf{1 9 9 7 - 2 0 0 0}$ & $\mathbf{2 0 0 1 - 2 0 0 5}$ & $\mathbf{2 0 0 6 - 2 0 1 0}$ & $\mathbf{2 0 1 1 - 2 0 1 5}$ \\
\hline $5 / 09$ & 4.15 & 3.71 & 4.60 & 4.38 & 3.92 \\
\hline $15 / 09$ & 4.34 & 4.03 & 5.08 & 4.84 & 4.39 \\
\hline $25 / 09$ & 4.35 & 3.70 & 5.09 & 5.01 & 4.70 \\
\hline $5 / 10$ & 4.05 & 3.41 & 4.10 & 4.71 & 4.77 \\
\hline $15 / 10$ & 2.81 & 2.57 & 3.36 & 3.73 & 4.43 \\
\hline
\end{tabular}

It was determined that the most favorable sowing date was September 25, as it is marked by the highest yield of winter wheat. Increasing the length of the growing season, increasing the sum of temperatures during the growing season, increased reception of PAR and total evaporation, increasing moisture lack to meet the requirements of the plants needs increasing the irrigation areas through the restoration of old irrigation systems and building new ones. And this, in its turn,

12 Вожегова Р.А., Малярчук М.П., Дробітько А.В. та ін. Наукове обгрунтування напрямів адаптації систем землеробства до кліматичних змін та забезпечення продовольчої безпеки. Наукові основи адаптації систем землеробства до змін клімату в Південному Степу України: колект. моногр. I за ред. чл.-кор. НААН Вожегової Р.А. Херсон : ОЛДІ-ПЛЮС, 2018. С. 8-39. 
requires significant expenditures of water resources, amount of which have not dropped in Ukraine and in the world, but they are distributed unevenly and in a different way.

To combat climate challenges, it is necessary to develop and implement innovative technologies for crops cultivation, implement systems for minimizing tillage (No-Till, Mini-Till), restore forest shelter belts to preserve soil moisture and prevent water and wind erosion, form scientifically substantiate crop rotations, and restore and expand irrigation systems.

\section{Modeling crops productivity on the level of an irrigated crop rotation}

Modern technologies for monitoring the state of agroecosystems are based on the use of sensors, i.e., devices of measuring, signaling, regulating or controlling nature, which converts a controlled quantity (temperature, pressure, frequency, light intensity, voltage, current, etc.) into a signal suitable for measurement, storage, processing, registration, to influence on the controlled processes ${ }^{13}$. It is known that a geographic information system (GIS) is an information system that provides the collection, storage, processing, access, display and dissemination of spatially coordinated data (spatial data). GIS contains data on spatial objects in the form of their digital representations (vector, raster, quadrotomy, etc.) ${ }^{14}$.

The components of GIS include: hardware - computer equipment of the institution to work with GIS, can be both a centralized server and computers connected by a single network; software - a software shell that contains the necessary tools for storing, processing and visualizing information; databases - a set of data, usually in tabular form, which allows automated processing of stored information, can be edited by the user using a database (database management system); qualified personnel - trained staff to work with GIS; scientific and methodological

${ }^{13}$ Vozhehova R. A., Lavrynenko Y. O., Kokovikhin S. V., Lykhovyd P. V., Biliaieva I. M., Drobitko A. V., Nesterchuk V. V. Assessment of the CROPWAT 8.0 software reliability for evapotranspiration and crop water requirements calculations. Journal of water and land development. 2018. No39. (X-XII). P. 147-142.

14 Smith M. CLIMWAT for CROPWAT: A climatic database for irrigation planning and management. FAO Irrigation and Drainage Paper. 1993. No. 49. Rome, Italy: Food and Agriculture Organization of the United Nations (FAO). P. 21-25. 
support - a rational work plan, drawn up in accordance with the specifics of the task ${ }^{15,16}$.

Information can come from the satellite on the weather forecast and crop status. For example, with the help of spectral analysis of the color of the fields, it is possible to obtain the information on the dynamics of the vegetation index, the plant density and the manifestation of water stress. Combining these and other data, it is possible to plan and quickly change the elements of cultivation technologies, in particular, irrigation rates, fertilization doses for feeding, the number of treatments with pesticides and biological preparations, etc. ${ }^{17}$.

The purpose of the study was to develop scientific and practical approaches to planning and operational management of irrigation schedules for crops using information technology in the South of Ukraine.

Field experiments were conducted according to the methodology of scientific work $^{18}$ during 2016-2019 at the experimental field of the Institute of Irrigated Agriculture of NAAS. The relief of the experimental area is flat. The soil of the experimental plot is dark-chestnut, slightly saline, middle-loamy one. Irrigation was carried out with the water from the Ingulets irrigation system. The cultivation technology of the studied crops was generally accepted for the conditions of irrigation of the Southern Steppe of Ukraine.

Modeling the parameters of production processes of the studied crops for planning and operational management of irrigation regimes was performed using the computer program of $\mathrm{FAO}^{19}$ - CROPWAT 8.0 for Windows. This program can be used by scientists and practitioners to

15 WOFOST. URL : https://www.wur.nl/en/Research-Results/ResearchInstitutes/Environmental-Research/Facilities-Products/Software-andmodels/WOFOST/Support-WOFOST.htm (дата звернення 01.10.2020).

16 Zessner M., Schönhart M., Parajka J., Trautvetter H. A novel integrated modelling framework to assess the impacts of climate and socio-economic drivers on land use and water quality. Science of The Total Environment. 2017. Vol. 579. P. 1137-1151. URL : http://dx.doi.org/10.1016/j.scitotenv.2016.11.092.

${ }^{17}$ Sadras V. O., Cassman K. G. G., Grassini P. and etc. Yield gap analysis of field crops. Methods and case studies. FAO Water Reports. Rome, Italy. 2015. No. 41.82 p.

18 Ушкаренко В.О., Вожегова Р.А., Голобородько С.П., Коковіхін С.В. Статистичний аналіз результатів польових дослідів у землеробстві: монографія. Херсон : Айлант, 2013. 403 с.

19 Crop Water and Irrigation Requirements Program of FAO (CROPWAT). URL : http://www.fao.org/land-water/land/land-governance/land-resources-lanningtoolbox /category/details/en/c/1026559 (дата звернення 21.03.2019). 
calculate the elements of soil water regime, water scarcity and crops requirements for irrigation based on the use of local data on soil, climate and crop condition, as well as their modeling to adjust the technological process of agricultural production. In addition, the program allows you to form schedules of irrigation for different economic conditions, to calculate water supply schemes depending on the levels of the planned yield. To determine the water demand of crops we used the calculated evapotranspiration (average daily evaporation) using the method of Penman-Monteith $^{20}$. This method takes into account both the physiological parameters of plants and climatic features of a particular soil-climatic zone. The CROPWAT program used meteorological data from Kherson Agrometeorological Station, which is located near the studied field of the Institute of Irrigated Agriculture of NAAS ${ }^{21}$.

The analysis of meteorological conditions in the years of the study testifies about significant fluctuations in the average daily temperatures and relative humidity - from $8.5^{\circ} \mathrm{C}$ below zero in January 2016 to 25.4-25.5 ${ }^{\circ} \mathrm{C}$ in August 2017 and 2018 (Fig. 4).

Relative humidity indices had a clear relationship of up to $46-60 \%$ in the hottest summer months (July, August) and had risen to $84-91 \%$ in winter (December, January).

The average monthly wind speed did not depend on the season and varied from $1.6 \mathrm{~m} / \mathrm{sec}$ in January 2016 to $3.6 \mathrm{~m} / \mathrm{sec}$ in November 2019 .

The duration of sunlight was connected with temperatureregime and relative humidity of air. Thus, the maximum rates of solar radiation were 26.1-26.3 MJ $/ \mathrm{m}^{2}$ per day in June 2017 and 2019, and in the autumn and winter (December 2017, November 2016) they decreased by 6.1-6.5 times - up to 4.1-4.3 $\mathrm{MJ} / \mathrm{m}^{2}$ per day.

In all the years of the study, this index was the greatest in the summer months with the highest air temperature and solar radiation. The maximum value $\mathbf{- 5 . 8 2} \mathrm{mm}$, evapotranspiration acquired in August 2018 . The average monthly rainfall fluctuated significantly - from $0.2 \mathrm{~mm}$ in January 2016 to $93 \mathrm{~mm}$ in June 2019.

${ }^{20}$ Smith M. CLIMWAT for CROPWAT: A climatic database for irrigation planning and management. FAO Irrigation and Drainage Paper. 1993. No. 49. Rome, Italy: Food and Agriculture Organization of the United Nations (FAO). P. 21-25.

21 Vozhehova R. A., Kokovikhin S. V., Lykhovyd P. V., Vozhehov S. H., Drobitko A. V. Artificial croplands and natural biosystems in the conditions of climatic changes: Possible problems and ways of their solving in the South Steppe Zone of Ukraine. Research Journal of Pharmaceutical, Biological and Chemical Sciences. 2018. November-December. Vol. 9(6). P. 331-340. 
The amount of precipitation fluctuated the most in the summer months. It should be mentioned that the maximum deficit of precipitation in the dry years of 2017 and 2019 appeared in August, which justifies the need to use irrigation to overcome the acute shortage of natural moisture supply.

Evapotranspiration, which is crucial for high yields, has also been closely connected with meteorological indices.

\begin{tabular}{|c|c|c|c|c|c|c|c|c|c|c|c|c|c|}
\hline & & & \multicolumn{4}{|c|}{2016} & & & \multicolumn{2}{|c|}{2017} & & & \\
\hline \multicolumn{7}{|c|}{ 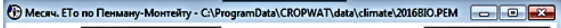 } & \multicolumn{7}{|c|}{ 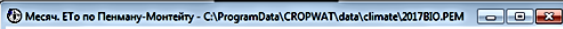 } \\
\hline \multicolumn{2}{|c|}{ CTpano Yrossoms } & & & \multicolumn{3}{|c|}{ Cronturas $\longdiv { \text { Xepcortispo } }$} & \multicolumn{2}{|c|}{ Crpama Yrossers } & & & \multicolumn{3}{|c|}{ Cranaus $\longdiv { \text { Xepcompard } }$} \\
\hline \multicolumn{2}{|c|}{ A6c. oucora $\longdiv { 5 4 } \mathrm { m }$} & \multicolumn{3}{|c|}{ Unpora $\longdiv { 4 6 . 3 7 } \longdiv { \tau }$} & \multicolumn{2}{|c|}{ Долтов $\longdiv { 3 2 3 6 } \longdiv { 8 }$} & A6c.socora & - & \multicolumn{3}{|c|}{ Wupora $\longdiv { 4 7 . 3 7 } \longdiv { \mathrm { C } }$} & \multicolumn{2}{|c|}{ 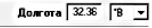 } \\
\hline \multirow[t]{2}{*}{ Mecos } & Cp remn & 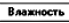 & Betep & Conat.coet & Pan & ETo & Mec9s & Cp remin & \begin{tabular}{|l|l|} 
Bлахнесть \\
\end{tabular} & Betrep & Cona.coet & Pas & ETO \\
\hline & ${ }^{\circ} \mathrm{C}$ & 7 & $\mathrm{~m} / \mathrm{c}$ & 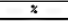 & MД*/MN/Cyr & Mancyman & & ${ }^{c} \mathrm{c}$ & $\%$ & $\mathrm{~m} / \mathrm{c}$ & $\%$ & MLW/Mn/CyT & 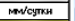 \\
\hline 9moopt & 8.5 & 84 & 1.6 & 92 & 81 & 0.16 & Яlusapb & 47 & 85 & 3.2 & 39 & 4.8 & 0.36 \\
\hline Феврам & 40 & 86 & 3.2 & 48 & 8.1 & 0.62 & $\Phi_{\text {enpant }}$ & 0.7 & 84 & 31 & 50 & 8.0 & 0.52 \\
\hline Mapr & 63 & 78 & 3.6 & 52 & 125 & 1.42 & Mapr & 7.1 & 73 & 30 & 59 & 130 & 1.57 \\
\hline Anpesto & 126 & $\pi$ & 3.2 & 58 & 17.7 & 270 & Anpeab & 93 & 72 & 2.7 & 49 & 16.1 & 218 \\
\hline MaA & 162 & 76 & 1.9 & 47 & 18.9 & 304 & MaA & 16.3 & 65 & 24 & 60 & 21.3 & 3.66 \\
\hline Howte & 220 & 69 & 2.0 & 56 & 22.1 & 4.36 & Hono & 220 & 51 & 2.2 & 76 & 25.3 & 5.22 \\
\hline Honts & 24.4 & 58 & 2.1 & 37 & 17.5 & 453 & Иøom & 23.4 & $\infty$ & 23 & 78 & 25.7 & 5.42 \\
\hline Abrget & 24.7 & 59 & 2.7 & 28 & 13.6 & 4.37 & Aorger & 25.4 & 51 & 2.7 & 80 & 225 & 576 \\
\hline Cenrsopb & 17.9 & 63 & 2.2 & 28 & 10.6 & 291 & Cenrragos & 19.9 & 51 & 2.5 & 79 & 17.2 & 3.75 \\
\hline Oкта6рь & 84 & 80 & 2.5 & 52 & 9.6 & 1.32 & 0kra6p6 & 11.3 & 76 & 30 & 40 & 8.2 & 1.62 \\
\hline Hoabpt & 4.0 & 87 & 3.1 & 20 & 4.4 & 0.63 & Hor6pb & 54 & 87 & 28 & 39 & 5.3 & 0.57 \\
\hline Дexa6pt & 1.2 & 87 & 3.3 & 39 & 4.4 & 0.41 & Dexo6pt & 59 & 87 & 2.7 & 40 & 4.1 & 0.50 \\
\hline \multirow[t]{2}{*}{ Cpeantag } & 10.9 & 75 & 2.6 & 46 & 12.3 & 2.21 & Сревняя & 11.7 & 72 & 2.7 & 57 & 14.4 & 2.59 \\
\hline & & & 2018 & & & & & & & 019 & & & \\
\hline \multicolumn{3}{|c|}{ (1) Mecau. ETo no Пенману-Morreйity - LI } & Cr $20200 \mathrm{anaC}$ & pWaticlimatel & 118810.PEM & 무뭄 & \multicolumn{7}{|c|}{ 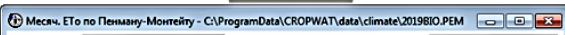 } \\
\hline \multicolumn{2}{|c|}{ Страна Yкраны: } & & & \multicolumn{2}{|c|}{ Станания } & & \multicolumn{2}{|c|}{ Crpano Yxpsoms } & & & \multicolumn{2}{|c|}{ CTansus ХepcontAsp } & \\
\hline AGc.eucoto 5 & м. & \multicolumn{3}{|c|}{ 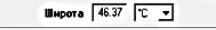 } & Дourrora $\Gamma$ & $\overline{3236}$ & AGc.oucota & - $m$ & Ump & $\longdiv { 4 6 . 3 7 }$ & 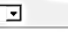 & Doarrora & $3 6 \longdiv { 8 }$ \\
\hline Mecram & Cp remn & \begin{tabular}{|l|} 
Bnazнoctb \\
\end{tabular} & Beтер & \begin{tabular}{|l|} 
Com.cвet \\
\end{tabular} & $P_{a x}$ & ETo & Mecrsu & Cp remn & OAnomnoctb & Betrep & Coman.coer & Pos & ETo \\
\hline & c & 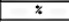 & $M / 0$ & $\%$ & MAN/mN/cyr & newcoyrin & & ${ }^{\circ} \mathrm{C}$ & $x$ & M/c & $x$ & $M Д * / m / N$ cyr & меvсудпи \\
\hline Янеарь & 0.4 & 88 & 32 & 39 & 5.0 & 0.37 & Яноерь & 0.6 & 91 & 3.2 & 40 & 5.1 & 0.32 \\
\hline Февpans & 0.3 & 88 & 33 & 40 & 7.5 & 0.54 & $\Phi_{\text {espono }}$ & 1,4 & 84 & 3.3 & 50 & 8.3 & 0.86 \\
\hline Mopt & 1.5 & 86 & 35 & 38 & 10.7 & 0.82 & Mapr & 5,8 & 70 & 3,3 & 59 & 13.4 & 1.64 \\
\hline Anpermo & 14.1 & 58 & 28 & 78 & 21.0 & 3.40 & Anpest & 10,5 & 65 & 3,0 & $\infty$ & 18.0 & 2.66 \\
\hline MaÂ & 19.5 & 59 & 25 & 79 & 25.2 & 4.76 & MoA & 18.0 & 73 & 2.2 & 58 & 21.1 & 3.52 \\
\hline Hoots & 22.9 & 51 & 21 & $\infty$ & 230 & 5.27 & Иort & 23.8 & 54 & 2.8 & 75 & 26,1 & 5.51 \\
\hline Unonb & 24.2 & 61 & 20 & 59 & 21.9 & 4.92 & ИøAb & 23,1 & 58 & 2,4 & 78 & 25,8 & 5,56 \\
\hline ABrycr & 25.5 & 46 & 2.5 & $\notin$ & 20.6 & 5.69 & Aorgct & 23.4 & 58 & 2.7 & 70 & 21.0 & 5.04 \\
\hline Cerrs960 & 18.7 & 64 & 26 & 58 & 14.6 & 333 & Cenrrgope & 18.1 & 59 & 2.7 & 76 & 17.0 & 3.66 \\
\hline $0 \mathrm{kT}, \mathrm{G} \mathrm{pb}$ & 13.5 & 69 & 27 & 75 & 11.8 & 2.11 & Dктropb & 11,5 & 85 & 2.2 & 59 & 10,3 & 1,31 \\
\hline Hog6po & 27 & 83 & 3.2 & 39 & 5.6 & a.7 & Hoa6pt & 7.1 & 87 & 3.6 & 50 & 6.2 & 0.70 \\
\hline Дexabpb & 0.1 & 90 & 35 & 23 & 3.6 & 0.34 & Дexa6pb & 4.3 & 91 & 3,3 & 48 & 4.8 & 0.37 \\
\hline Cреаная & 11.8 & 70 & 2.8 & 55 & 14.2 & 2.69 & Среаняя & 12,2 & 74 & 2,9 & 60 & 14.8 & 2,58 \\
\hline
\end{tabular}

Fig. 4. The main meteorological indices in the years of the study (according to the data of Kherson agrometeorological station)

Variation analysis proved that the variability of precipitation in the conditional period of vegetation of the crops from March to September is: for $2016-40.9 \%$; for $2017-180.2$; for $2018-114.2$; for $2019-$ $103.0 \%$.

Under such natural conditions of the Southern Steppe of Ukraine, the role of irrigation is of a great importance for the possibility of obtaining crop products, especially in the absence of precipitation on the background of high temperatures and low air humidity. 
Taking into account the biological features of irrigated crops, the terms of their sowing (for winter wheat - the period of renovation of spring vegetation) we used CROPWAT program for modeling the main indices of the plant production in 2016 by conditional periods of development, including depth of root penetration, calculated coefficient of water regime, etc.

It is established that the total evapotranspiration for the period of corn vegetation in 2016 is $342.1 \mathrm{~mm}$. Such water use will be compensated by effective precipitation at the level of $159.1 \mathrm{~mm}$, and to overcome the moisture deficit in corn crops it is necessary to supply irrigation water, taking into account all types of unproductive losses $-207.2 \mathrm{~mm}$.

The irrigation schedule determines the need for vegetative irrigation with a net irrigation rate of $207.6 \mathrm{~mm}$. The actual use of water for irrigation (total water use) is $341.1 \mathrm{~mm}$, taking into account the deficit of moisture at harvest time at the level of $36.9 \mathrm{~mm}$.

The irrigation schedule determines how effectively the crop uses artificial humidification during the growing season. Irrigation efficiency in irrigation schedules is expressed as a percentage and is calculated as the ratio between the net irrigation rate, irrigation water losses during irrigation process, and the efficiency of irrigation water use by crops. The efficiency of precipitation use, expressed as a percentage, reflects the relationship between effective precipitation and the total contribution of precipitation to the growth and development of the crop during the growing season.

Non-compliance of the irrigation system with agrotechnical requirements, for example, lack of field planning when applying irrigation by strips or furrows, poor land leveling, low water absorption capacity of the soil, etc., can lead to the losses of irrigation water.

To account for the amount of water, which does not remain in the root zone, CROPWAT 8.0 allows to implement the evaluation of irrigation efficiency, which determines the depth of the active soil layer, optimizes irrigation water and other resources for each crop rotation, taking into account crop features.

On average, over the years of the study, it was found that the actual irrigation rate exceeds the simulated indices on all the crops by $18-50$ mm (Fig. 5). 


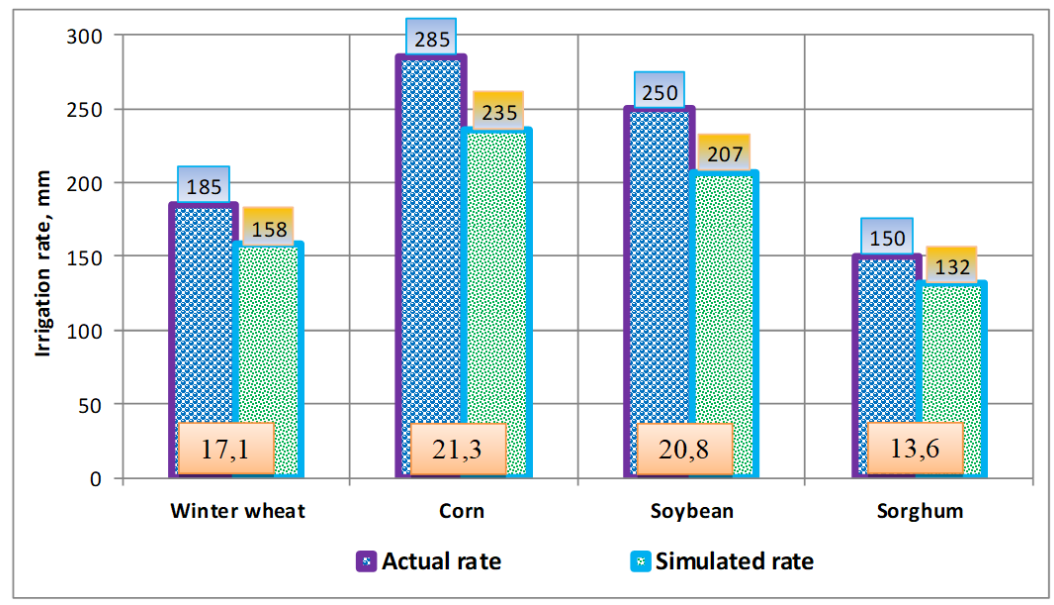

Fig. 5. Indices of actual and simulated in the program CROPWAT irrigation rates for the crops in the crop rotation, $\mathbf{m m}$ (average for 2016-2019)

For winter wheat, this excess was $17.1 \%$; for corn - 21.3; for soybean -20.8 ; for sorghum $-13.6 \%$. The calculations have proven that under crops cultivation on the irrigated lands it is necessary to take into account a set of natural and anthropogenic factors.

Besides, to optimize the agro-technological process of crops cultivation on the irrigated lands, it is required to use information technology and special computer programs by the main parameters of the production process - biological properties of a particular crop of an irrigated crop rotation, projected yield, artificial humidification method, fertilization systems, tillage and plant protection, etc.

On average, over the years of the study, it has been determined that thermal energy factors are utilized the best by the early and middleripening hybrids, which have a temperature index of 304.1 and 305.1 and the coefficients of PAR use efficiency of $2.15 \%$. In the late-ripening hybrids there was an increase in $T_{i}$ by $5.1-5.4 \%$ and a decrease in $\eta_{f}$ by $2.4 \%$, respectively.

Variation and correlation analysis allowed to establish different in strength and direction relationships of corn yield with the main thermal factors (Table 2). 
Table 2

Grain yields of corn hybrids of different ripening groups depending on natural moisture supply and heat and energy indices

\begin{tabular}{|c|c|c|c|c|c|c|c|c|}
\hline \multirow[b]{2}{*}{$\begin{array}{l}\text { Moisture } \\
\text { supply of } \\
\text { the years }\end{array}$} & \multirow{2}{*}{$\begin{array}{c}\text { Ripening } \\
\text { group of } \\
\text { the } \\
\text { hybrids }\end{array}$} & \multicolumn{7}{|c|}{ Indices } \\
\hline & & $\begin{array}{c}- \\
x, \\
\text { t/ha }\end{array}$ & $\underset{{ }^{\circ} \mathbf{C}}{\mathbf{\Sigma} T,}$ & $T_{u}$ & $\begin{array}{c}E_{V}, \\
\text { GJ/ha }\end{array}$ & $\underset{\text { GJ/ha }}{Q,}$ & $\underset{\text { GJ/ha }}{Q_{\Phi},}$ & $\underset{\%}{\boldsymbol{\eta}_{f}}$ \\
\hline \multirow{3}{*}{ Humid } & early & 10.3 & 2318 & 226 & 330 & 22245 & 11345 & 2.91 \\
\hline & middle & 11.5 & 2697 & 235 & 370 & 26889 & 13714 & 2.72 \\
\hline & late & 12.6 & 2915 & 233 & 404 & 29630 & 15112 & 2.68 \\
\hline \multirow{3}{*}{$\begin{array}{l}\text { Moderately } \\
\text { humid }\end{array}$} & early & 7.7 & 2293 & 303 & 249 & 24590 & 12541 & 2.08 \\
\hline & middle & 9.1 & 2587 & 292 & 294 & 27541 & 14045 & 2.19 \\
\hline & late & 10.6 & 2957 & 285 & 343 & 31847 & 16242 & 2.20 \\
\hline \multirow{3}{*}{ Moderate } & early & 7.4 & 2156 & 294 & 240 & 21897 & 11168 & 2.15 \\
\hline & middle & 8.0 & 2509 & 317 & 256 & 25115 & 12809 & 2.00 \\
\hline & late & 8.1 & 2840 & 352 & 261 & 29141 & 14862 & 1.76 \\
\hline \multirow{3}{*}{$\begin{array}{c}\text { Moderately } \\
\text { dry }\end{array}$} & early & 7.4 & 2092 & 296 & 237 & 21222 & 10824 & 2.21 \\
\hline & middle & 8.7 & 2416 & 294 & 280 & 24506 & 12498 & 2.27 \\
\hline & late & 10.1 & 2707 & 281 & 324 & 27169 & 13857 & 2.37 \\
\hline \multirow{3}{*}{ Dry } & early & 5.9 & 2125 & 378 & 191 & 22732 & 11593 & 1.65 \\
\hline & middle & 7.0 & 2474 & 368 & 225 & 25785 & 13150 & 1.73 \\
\hline & late & 7.0 & 2760 & 441 & 227 & 28554 & 14563 & 1.58 \\
\hline \multirow{3}{*}{$\begin{array}{l}\text { On average } \\
\text { over the } \\
\text { years of the } \\
\text { study }\end{array}$} & early & 7.5 & 2182 & 304 & 243 & 22469 & 11459 & 2.15 \\
\hline & middle & 8.7 & 2518 & 305 & 279 & 25808 & 13162 & 2.15 \\
\hline & late & 9.5 & 2822 & 322 & 307 & 29104 & 14843 & 2.10 \\
\hline
\end{tabular}

Variation analysis of the yield data testifies about their stability in humid, moderate and moderately humid years, as the coefficient of variation ranges from 9.2 to $10.4 \%$. However, in moderately dry and dry years, there is an increase in grain productivity of corn in 2.5-2.9 times ( $V$ is 25.8 and $26.6 \%$ ).

Estimation of the variation of thermal resources proved the stability of the sum of temperatures during the growing season, but also a significant difference in temperature index, which in humid years has little variability $(V=5.1 \%)$, average $(V=18.6$ and $12.4 \%)-$ in moderately humid and humid years, significant $(V=23.2$ and $33.5 \%)-$ in moderately dry and dry years.

The indices of photosynthetically active radiation income $\left(Q_{F}\right)$ differed in the average degree of variability with variations ranging from 11.2 to $19.7 \%$ (Table 3 ). 
Table 3

Results of statistical analysis of variability and relationships between thermal energy factors and the yield of grain corn

\begin{tabular}{|c|c|c|c|c|c|c|}
\hline \multirow{2}{*}{$\begin{array}{l}\text { Moisture } \\
\text { supply of a } \\
\text { year }\end{array}$} & \multirow[b]{2}{*}{ Coefficients } & \multicolumn{5}{|c|}{ Indices } \\
\hline & & $\begin{array}{c}\bar{x}, \\
\text { t/ha }\end{array}$ & $\underset{{ }^{\circ} \mathrm{C}}{\Sigma \mathrm{T}}$ & $T_{u}$ & $\underset{\text { GJ/ha }}{Q_{F},}$ & $\begin{array}{l}n_{f} \\
\%\end{array}$ \\
\hline \multirow{3}{*}{ Humid } & Variation, $V, \%$ & 9.2 & 11.4 & 5.1 & 13.5 & 6.5 \\
\hline & Correlation, $r$ & - & 0.90 & 0.23 & 0.91 & 0.49 \\
\hline & Determination, $R^{2}$ & - & 0.81 & 0.05 & 0.82 & 0.24 \\
\hline \multirow{3}{*}{$\begin{array}{l}\text { Moderately } \\
\text { humid }\end{array}$} & Variation, $V, \%$ & 10.4 & 12.4 & 18.6 & 19.7 & 31.6 \\
\hline & Correlation, $r$ & - & 0.31 & -0.80 & -0.17 & 0.77 \\
\hline & Determination, $R^{2}$ & - & 0.10 & 0.64 & 0.03 & 0.59 \\
\hline \multirow{3}{*}{ Moderate } & Variation, $V, \%$ & 9.2 & 12.3 & 12.4 & 12.6 & 12.8 \\
\hline & Correlation, $r$ & - & 0.36 & -0.41 & 0.34 & 0.40 \\
\hline & Determination, $R^{2}$ & - & 0.13 & 0.17 & 0.11 & 0.16 \\
\hline \multirow{3}{*}{$\begin{array}{l}\text { Moderately } \\
\text { dry }\end{array}$} & Variation, $V, \%$ & 25.8 & 11.7 & 23.2 & 11.5 & 26.2 \\
\hline & Correlation, $r$ & - & 0.41 & -0.89 & 0.16 & 0.90 \\
\hline & Determination, $R^{2}$ & - & 0.17 & 0.78 & 0.03 & 0.81 \\
\hline \multirow{3}{*}{ Dry } & Variation, $V, \%$ & 26.6 & 12.1 & 33.5 & 11.2 & 26.7 \\
\hline & Correlation, $r$ & - & 0.20 & -0.86 & 0.03 & 0.92 \\
\hline & Determination, $R^{2}$ & - & 0.04 & 0.73 & 0.00 & 0.85 \\
\hline
\end{tabular}

The coefficient of PAR efficiency had the highest stability in the humid years $(V=6.5 \%)$, the average level $(V=12.8 \%)$ - in the moderate ones, and in others - had a high degree of variability $(V=26,2-31,6 \%)$.

The correlation analysis of the indices of natural heat supply showed interesting results. In the humid years, there is a very high degree of correlation between the sum of air temperatures and the level of grain corn yield with a correlation coefficient of 0.90 and determination of the yield level by $81 \%$ that is a cause of the restraining effect of air temperature under high humidity. In other by the evaporation deficit years the reduction of the correlation by 2.2-4.5 times was observed.

Similar dependences on corn productivity were found for photosynthetically active radiation index, as only in the humid years a high degree of connection $(r=0.91)$ was recorded at $81 \%$ level of the influence of grain yield formation of the studied crop.

In other by the levels of natural moisture supply years, there is a weak positive and negative relationship between these indices at correlation coefficients from -0.17 to 0.34 , and in the dry years - the relationship is almost absent $(r=0.03)$. It should be mentioned that the increase in the PAR CE had a positive effect on grain yield in all the years of the study, but the highest degree of relationships was observed in the moderately 
dry $(r=0.90)$ and dry $(r=0.92)$ years, when the effect of this factor determined the plant productivity by 81.0 and $85.0 \%$, respectively.

Correlation-regression modeling of corn grain yields depending on the sum of air temperatures during the growing season proved the best response to the improvement of the thermal regime in middle-ripening hybrids. On the contrary, early-ripening hybrids require less amounts of air temperatures and reduce yield increment starting from $1500-1600^{\circ} \mathrm{C}$. These patterns should be taken into account when selecting hybrids of different ripening groups for irrigated crop rotations.

\section{CONCLUSIONS}

Thus, to minimize the impact of climate change on agricultural production, it is necessary to develop directions of adaptation of agricultural production to different scenarios of climate change: development of agricultural systems with resource-saving, soil-saving elements of cultivation technologies, innovative tillage systems to reduce anthropogenic load on soils and decrease in greenhouse gases emission; improvemnet of the system of plant protection against diseases and pests; use of varieties and hybrids of crops, which are adapted to arid conditions and irrigation, as well as the crops with a short growing season; prevention of soil degradation, salinization and alkalinization, water and wind erosion; introduction of water-saving irrigation regimes and innovative methods of crops irrigation. The simulation results show that late-ripening corn hybrids have a certain stability of productivity increment as the sum of temperatures increases, which is associated with a long growing season and a decrease in thermal regime in late summer and especially in autumn in the final stages of the plant development. Negative direction of the plant productivity relationships was observed with respect to photosynthetically active radiation. The calculations support about a slow decrease in the yield of hybrids of all ripening groups with increasing PAR income, which is explained by the peculiarities of the climatic conditions of the Southern Steppe of Ukraine, which is characterized by high solar radiation resources and natural moisture deficit. Statistical analysis of the yield data of different by the ripening groups hybrids of corn and thermal energy indices allowed to establish different degrees and directions of the relationship between the plant productivity in the differentiation of natural humidification conditions during the years of the study. Assisted by the created correlation-regression dependences it is possible to model the yield level of different by the ripening groups corn hybrids by the actual indices of the sum of air temperatures and the receipt of photosynthetically active radiation during the growing season of the plants. 


\section{SUMMARY}

In the southern regions of Ukraine, the main factor limiting the realization of the biological and genetic potential of crops and reducing the efficiency of agro-ecological potential is the lack of moisture. Irrigation significantly eliminates this deficit and thus contributes to the increase in the efficiency of agroecological potential and the degree of its manifestation in the form of the actual level of yield.

The purpose of the study was to develop scientific and practical approaches to planning and operational management of irrigation schedules for crops using information technology in the South of Ukraine.

Taking into account the biological features of irrigated crops, the terms of their sowing we used CROPWAT program for modeling the main indices of the plant production by conditional periods of development, including depth of root penetration, calculated coefficient of water regime, etc.

The simulation results show that late-ripening corn hybrids have a certain stability of productivity increment as the sum of temperatures increases, which is associated with a long growing season and a decrease in thermal regime in late summer and especially in autumn in the final stages of the plant development. Negative direction of the plant productivity relationships was observed with respect to photosynthetically active radiation. The calculations support about a slow decrease in the yield of hybrids of all ripening groups with increasing PAR income, which is explained by the peculiarities of the climatic conditions of the Southern Steppe of Ukraine, which is characterized by high solar radiation resources and natural moisture deficit.

\section{References}

1. Гадзало Я.М., Вожегова Р.А., Коковіхін С.В., Біляєва I.М., Дробітько А.В. Наукове обгрунтування технологій вирощування кукурудзи на зрошуваних землях із урахуванням гідротермічних чинників і змін клімату. Зрошуване землеробство. Херсон, 2020. Вип. 73. С. 21-26.

2. Агрокліматичні ресурси півдня України та їх раціональне використання: монографія / Лимар А.О., Лимар В.А., Коковіхін С.В. Домарацький Є.О. Херсон : Грінь Д.С., 2015. 246 с.

3. Зубець М.В. Наукові основи агропромислового виробництва в зоні Степу України. Київ : Аграрна наука, 2004. С 359-363.

4. Жуйков Г.С., Димов О.М. Нормативи витрат матеріальнотехнічних ресурсів при вирощуванні основних зернових культур: науково-методичний посібник. Херсон : Айлант, 2004. 20 с. 
5. Іващенко О.О., Рудник-Іващенко О.I. Напрями адаптації аграрного виробництва до змін клімату. Вісн. аграр. науки. 2011. № 8. C. 10-12.

6. Ушкаренко В.О., Вожегова Р.А., Голобородько С.П., Коковіхін С.В. Статистичний аналіз результатів польових дослідів у землеробстві: монографія. Херсон : Айлант, 2013. 403 с.

7. Коковіхін С.В., Писаренко П.В., Пілярський В.Г., Ніколайчук М.Г., Нікішов О.О., Дробітько А.В. Оптимізація структури посівних площ на зрошуваних землях з урахуванням показників гідромодулю системи та біологічних потреб культур. Зрошуване землеробство: збірник наукових пращь. Херсон : Айлант, 2013. Вип. 60. С. 30-32.

8. Сайко В.Ф. Наукові основи землеробства в контексті змін клімату. Вісн. аграр. науки. 2008. № 11. С. 5-10.

9. Тараріко Ю.О. Розробка грунтозахисних ресурсо- та енергозберігаючих систем ведення сільськогосподарського виробництва 3 використанням комп'ютерного програмного комплексу. Київ : Нора-Друк, 2002. 122 с.

10.Полупан М.I., Соловей В.Б., Величко В.А. Класифікація грунтів України. Київ : Аграрна наука, 2005. С.144-156.

11.Третяк А.М., Бобміндра Д.І. Земельні ресурси України та їх використання. Київ, 2003. 144 с.

12. Вожегова Р.А., Малярчук М.П., Дробітько А.В. та ін. Наукове обгрунтування напрямів адаптації систем землеробства до кліматичних змін та забезпечення продовольчої безпеки. Наукові основи адаптації систем землеробства до змін клімату в Південному Степу України : колект. моногр. / за ред. чл.-кор. НААН Вожегової Р.А. Херсон : ОЛДІ-ПЛЮС, 2018. С. 8-39.

13. Vozhehova R. A., Lavrynenko Y. O., Kokovikhin S. V., Lykhovyd P. V., Biliaieva I. M., Drobitko A. V., Nesterchuk V. V. Assessment of the CROPWAT 8.0 software reliability for evapotranspiration and crop water requirements calculations. Journal of water and land development. 2018. No 39. (X-XII). P. 147-142.

14. Smith M. CLIMWAT for CROPWAT: A climatic database for irrigation planning and management. FAO Irrigation and Drainage Paper. 1993. No. 49. Rome, Italy: Food and Agriculture Organization of the United Nations (FAO). P. 21-25.

15.WOFOST. URL : https://www.wur.nl/en/Research-Results/ Research-Institutes/Environmental-Research/FacilitiesProducts/Software-and-models/WOFOST/Support-WOFOST.htm (дата звернення: 01.10.2020). 
16.Zessner M., Schönhart M., Parajka J., Trautvetter H. A novel integrated modelling framework to assess the impacts of climate and socio-economic drivers on land use and water quality. Science of The Total Environment. 2017. Vol. 579. P. 1137-1151. URL : http://dx.doi.org/10.1016/j.scitotenv.2016.11.092.

17. Sadras V. O., Cassman K. G. G., Grassini P. and etc. Yield gap analysis of field crops. Methods and case studies. FAO Water Reports. Rome, Italy. 2015. No. 41.82 p.

18. Ушкаренко В.О., Вожегова Р.А., Голобородько С.П., Коковіхін С.В. Статистичний аналіз результатів польових дослідів у землеробстві: монографія. Херсон : Айлант, 2013. 403 с.

19.Crop Water and Irrigation Requirements Program of FAO (CROPWAT). URL : http://www.fao.org/land-water/land/landgovernance/land-resources-lanning- toolbox /category/details/en/c/ 1026559 (дата звернення: 21.03.2019).

20.Smith M. CLIMWAT for CROPWAT: A climatic database for irrigation planning and management. FAO Irrigation and Drainage Paper. 1993. No. 49. Rome, Italy: Food and Agriculture Organization of the United Nations (FAO). P. 21-25.

21. Vozhehova R. A., Kokovikhin S. V., Lykhovyd P. V., Vozhehov S. H., Drobitko A. V. Artificial croplands and natural biosystems in the conditions of climatic changes: Possible problems and ways of their solving in the South Steppe Zone of Ukraine. Research Journal of Pharmaceutical, Biological and Chemical Sciences. 2018. November-December. Vol. 9(6). P. 331-340.

\section{Information about the authors: Piliarska Olena Oleksandrivna,}

Candidate (PhD) of Agricultural Sciences, Senior Research Fellow Institute of Irrigated Agriculture of National Academy of Agrarian Sciences of Ukraine Naddnipryanske sett., 73483, Kherson region, Ukraine

Kokovikhin Serhii Vasylovych, Doctor of Agricultural Sciences, Professor, Deputy Director Institute of Irrigated Agriculture of National Academy of Agrarian Sciences of Ukraine Naddnipryanske sett., 73483, Kherson region, Ukraine 